\title{
Economic Growth Creation or Diversion? \\ The Record of Trade Agreements in Latin America
}

\author{
Gustavo Barboza \\ Clarion University of Pennsylvania $\cdot$ Clarion, PA \\ Sandra Trejos ${ }^{1}$ \\ Clarion University of Pennsylvania • Clarion, PA
}

\section{Abstract}

This paper examines the effects of Preferential Trade Agreements (PTAs) and GATT/WTO membership on economic growth using a sample of seventeen Latin American countries for the period 1950-2004. In general, the evidence indicates that the proliferation of bilateral and multicountry regional and extra regional trade agreements has not resulted in faster economic growth. On the contrary, we find that PTAs and WTO only have a weak positive effect on increasing trade openness; but this relationship does not translate into faster economic growth when controlling for capital, labor force and trade openness. These results are robust to both static and dynamic model specifications, indicating that trade openness has a positive effect on per capita output growth, but PTA and WTO membership do not. Integration via de facto increases output growth while integration via de jure does not. Based on the results, PTAs create a net diversion effect on economic growth.

\section{Introduction}

Economists are known for disagreeing in many things. However, when it comes to trade, there is an overwhelming consensus that free trade is good. More so, they convey that - in most circumstances - freer trade is preferred over restricted trade, and more trade is preferred to less. The underlying assumption is that trade is an engine for economic growth. In this regard, economic reform moves countries from protectionism to freer trade regimes. The recent reform process has been characterized by a predominant proliferation of preferential trade agreements (PTAs) (both regional and extra regional), over multilateral negotiations along the lines of the GATT/WTO. A part of the proliferation of PTAs over multilateral liberalization is the result of a failure to achieve consensus as exemplified in the Doha-Round trade negotiations. However, with regard to PTAs, the contentious issue is whether integration through agreements - de jure - generates greater gains in relation to integration through market - de facto. In other words, do PTAs substitute or complement multilateral trade integration and do PTAs generate positive or pervasive 
effects on economic growth? Thus, there exists much controversy on the effects of PTAs on trade (diversion versus creation) and consequent effects on economic growth. Latin America is one particular economic region of interest, because of its fast adoption of PTAs.

Latin America and the Caribbean is an economic region composed of about 34 countries with an estimated combined market size of 400 million people. According to Cardoso and Helwege (1995), the proliferation of preferential trade agreements in Latin America, under the inward looking import substitution industrialization period, partially explains the underdevelopment observed in this region. It is during this period that regional preferential trade agreements, such as the Central American Common Market (CACM) and the ANDEAN pact, were implemented. ${ }^{2}$ The growth paradox of these agreements is that while promoting more trade within the members, they were discriminatory to non-members, with the consequent degeneration into a net trade diversion effect. However, in an effort to restore the region's international competitiveness and promote dynamic industrial and service sectors, most Latin American countries have decisively implemented market-friendly reforms since the early 1980s. The new mantra emphasizes the promotion of freer trade as the engine of economic growth. As a result of the new economic and political regimes, there has been a surge and proliferation of intra and extra regional trade agreements, making the region a showcase for trade liberalization (Kuwayama, Duran, \& Silva, 2005).

The proliferation of PTAs over multilateral agreements has been in part the result of specific applications of Article XXIV of the GATT that allows for the formation of PTAs, provided that those agreements cover substantial trade, free trade is the ultimate goal among members, and do not increase protection to the rest of the world (Krueger, 1999). Thus, as a result of this clause and the failure to move forward general agreements such as the Doha Round, there are currently about 200 PTAs around the world. This number is projected to increase to about 400 in the next decade. Saggi and Yildiz (2008) indicate that countries are, freely and willingly, engaged in PTAs over the alternative of multilateral liberalization. Latin America is no exception as Jurn and Park (2002) and Kuwayama et al. (2005) argue. However, a clear and relevant difference between multilateral liberalization and PTAs is that the former gives symmetric treatment to all countries while the latter takes many forms ranging from intra-regional bilateral to extra-regional multicountry, resulting in asymmetric preferences given to members over non-members. Gouvea \& Hranaiova (2002) indicate that while these trade reforms are setting the ground for further integration toward the creation of the Free Trade Agreement of the Americas, much controversy remains as to whether this is the case. Therefore, understanding 
the impact that international trade reform, and, specifically, the role that freer international trade has on output growth in both short-run and long-run is of relevance to all parties involved. In this context, given the proliferation of Preferential Trade Agreements (PTA) as one of the main mechanisms to advance the trade reform process, the following questions become relevant: i) can PTAs be equated with freer trade movements, stepping stones, or do they turn into stumbling blocks, moving economies away from multilateral free trade and further economic integration?, and, ii) are PTAs trade creating or trade diverting in nature, and thus, do they promote or retard economic growth? This paper pays particular attention to the latter question, while acknowledging the relevance of the former.

The paper uses conventional well known economic theory and econometric analysis (static and dynamic estimations) to address the posted question, looking at the Latin America case. The originality of this paper rests on the relevance of its findings, as it provides a direct account of the effect and direction of PTAs on the rate of growth of output, addressing the overarching question of whether PTAs are economic-growth creating or economic-growth diverting. The paper is organized as follows. The next section provides a comprehensive review of the literature on trade openness and the role of PTAs. Section III outlines the model specification under the static and dynamic conditions. Section IV describes the data, presents the main findings and their corresponding analysis. Section $\mathrm{V}$ concludes and provides policy recommendations and overall implications.

\section{On the goodness of free trade and freer trade reform. The role of PTAS.}

From a theoretical point of view most economists agree that trade is good with open economies growing faster than otherwise. ${ }^{3}$ For instance, a large body of literature addresses the positive effects that export (trade) growth has in per capita output growth. ${ }^{4}$ Barboza (2007) provides an extensive review of the literature and notes that not only one should look at the favorable role of export on economic growth, but most importantly to the fact that if trade increases economic growth, other transmission mechanisms should be considered, such as the role of trade on: transfer of technology, generation of economies of scale, learning-by-doing and development of the R\&D (see Edwards, 1992; Romer, 1986, 1990, 1994; Grossman \& Helpman, 1990, 1994; Keller, 2002; Dowrick \& Golley, 2004; among others).

With the objective of obtaining the benefits of expanded trade as indicated above, developing countries have resorted to the implementation of PTAs of various sorts in the wake of failed multilateral negotiations. Kuwayama et al. (2005) are 
prompt to indicate that Latin America is a showcase of PTAs in this regard. However, Viner's (1950) pioneering work on the welfare effects of custom unions warns of the possible negative effects of these agreements on both members and world welfare. In addition, as Bhagwati (I991) indicates, the drawback of PTAs is that they have the potential to create a trade-diversion effect over multilateral trade negotiations. In the words of Bhagwati (1991), PTAs have the potential to be either "stepping stones or stumbling blocks" to a more integrated and highly efficient trading system. Therefore, countries pursuing economic integration through PTAs may see an increase in trade flows for participating members, with a negative consequence on overall economic growth, as trade diversion substitutes cheaper imports from non-member parties. Krueger (1999) points out that short term gains derived from PTAs may compromise long term economic perspectives, if PTAs move countries away from multilateralism. That is, PTAs could divert trade from nonmember nations to members, given that the agreement takes away competitiveness from countries that do not belong to the agreement. Consequently, the potential trade diversion effect, while increasing overall trade, may reduce economic wellbeing. An interesting consideration is brought forth by Saggi and Yildiz (2008). They indicate that countries engage in PTAs endogenously over the unilateral and multilateral trade liberalization. Soloaga and Winters (1999) indicate that "the effect of PTAs on trade is still an open question" (p2). In general, Foroutan (1998) acknowledges that "belonging to a regional scheme constitutes neither a necessary nor a sufficient condition for an open and liberal trade regime (p.11).

Krueger (1999) also recognizes the fact that the effect of PTAs on participants' wellbeing could result in asymmetric outcomes from a common trade agreement, depending on each country's own situation. Relatively speaking, though, countries that are not part of the preferential agreement would lose trade, ceteris paribus. Furthermore, Krueger states that gains from trade agreements in terms of welfare are lower when countries with similar factor endowments trade, relative to when countries have different endowments. For instance, Jurn and Park (2002), studying Mercosur, note the existing controversy about how the regional agreement is advancing the cause of multilateral liberalization. Whether this is the case may be assessed by examining the net trade-creating or trade-diverting effects of the agreements (Jurn \& Park, 2002). Yeats (1997) finds significant evidence of trade diversion effects in the case of MERCOSUR, and indicates that the data analysis finds similar results at the aggregate macro level for the four founding members: Brazil, Argentina, Uruguay, and Paraguay.

In the more general case of the entire Latin America region, Aminian et al. (2008), indicate that Latin America has primarily used formal regional trade trea- 
ties as the main channel of integration. However, Latin America is less integrated than is East Asia, although the latter region has relatively less formal regional trade treaties. ${ }^{5}$ Duran, Mulder, and Onodera (2008) find out that although Latin America implemented tariff liberalization at an earlier stage than East Asia, reductions in non-trade barriers were faster in East Asia than in Latin America. Also, Duran et al. (2008) discuss how the macroeconomic environment of overvalued exchange rates, high inflation and high interest rates combined with low and volatile growth may have reduced the effects of trade reform.

Finally, from an empirical point of view, the openness-output relationship has been studied traditionally using static model specifications. Empirical results derived from static model specifications point out to the existence of a positive relationship between export (trade) growth and output growth, yet they are not conclusive. Significant controversy remains as a key element when proposing trade reforms. With these considerations in mind we now turn to the model specification.

\section{$\overline{\text { Model }}$}

To determine the effects of PTAs on output growth, let us start our analysis by outlining a static model specification similar to the one previous studies have used (Feder, 1982; De Gregorio, 1992; Mbaku, 1989; Kavoussi, 1984; Ram, 1985; Moschos, 1989; Knight, Loayza, \& Villanueva, 1993; Tyler, 1981; and Moran, 1983). We specify a simple production function that identifies the basic factors (labor and capital) that contribute to economic growth, augmented to include trade openness as an additional factor of production as presented in Strauss and Ferris (1996), among others. We assume that openness enables the exploitation of economies of scale, transfers technology, promotes reallocation of resources according to comparative advantage, and allows greater capacity utilization, and increased employment in labor surplus countries (Grossman \& Helpman, 1990, 1991, 1994; Aghion \& Howitt, 1998; Harrison, 1996; Edwards, 1992, 1993; Ben-David \& Loewy, 1998). Thus, the basic model is represented by the production function:

$$
Q_{i t}=f\left(K_{i p}, L_{i r}, X_{i t}\right)
$$

where $Q_{i t}$ is the real Gross Domestic Product, $K_{i t}$ is the capital stock, $L_{i t}$ is the labor force and $X_{i f}$ is the degree of trade openness for country $i$ in period $t$. Total differentiation with respect to time and dividing through by equation 1 , yields: ${ }^{6}$ 


$$
y_{i, t}=\alpha+\beta k_{i, t}+\delta t_{i, t}+\psi x_{i, t}
$$

where $y_{i, \ell}$ is the rate of growth of output, $k_{i, t}$ is the rate of growth of capital stock, $l_{i, l}$ is the rate of growth of the labor force, and $x_{i, t}$ is the rate of growth of openness, where it is assumed that the rate of technological change is a linear function of the openness growth rate as expressed by $\psi \cdot \beta, \delta$, and $\psi$ are the elasticities of output with respect to capital, labor, and trade openness respectively, and $\alpha$ is the growth rate of unexplained total factor productivity. By approximating the rate of growth of the capital stock by the investment-output ratio (Ram, 1985; Feder, 1982; and Mbaku, 1989; among others) times the rate of growth of the capital stock, and replacing the change in the capital stock with the investment rate, $I$, we obtain,

$$
y_{i, t}=\alpha_{0}+\lambda \frac{I_{i, t}}{Q_{i, \ell}}+\delta l_{i, t}+\psi x_{i, t}
$$

Now $\lambda$ is the marginal physical output of capital. Expected parameter signs are: $\lambda>0$ (more capital per worker increases labor productivity), $\delta<0$ (more workers per unit of capital reduce labor productivity), and $\psi>\theta$ (more openness increases labor productivity). Additionally, to expand and simultaneously control for the effects of the formation of PTAs (Bilateral and Multicountry, both regional and extra regional) and WTO (Multilateral) membership, we include a set of categorical variables as indicated in equation 4 below. If PTAs are growth-creating, then the corresponding coefficients will have a positive sign and if they are growth diverting, the coefficients will have a negative sign. Finally, we add a time dummy variable for each decade - between 1950-2004 - to account for possible time effects (see Aminian et al., 2008). The resulting equation is,

$$
y_{i, t}=\alpha_{0}+\lambda \frac{I_{i, t}}{Q_{i, t}}+\delta l_{i, t}+\psi x_{i, t}+\sum_{j=l}^{4} \varphi P T A_{j i, t}+\omega W T O_{i, t}+\sum_{j=l}^{6} \rho_{j} T_{j}+e_{t}
$$

where $\varphi_{j}$ corresponds to each PTA type, $j$, with the null hypothesis that it is positive if PTAs are growth creating, and negative if they are growth diverting. $\omega$ corresponds to the effect that being a member of the WTO has on output growth and we test the null hypothesis that multilateral trade agreements are growth creating, thus $\omega>0$. Finally, $\rho_{j}$ could be positive or negative depending on the time-specific effects. 


\section{Dynamic Growth Effects}

The main limitation of static models, such as the one outlined in (4) above, is that they do not permit for a full decomposition of results between short-run and long-run. This decomposition is a primary interest of this paper, since we desire to determine the effects of PTAs on output growth and their effect on factors of production as they relate to output growth. Alternatively, a dynamic model specification is more appropriate to capture spillover effects deriving from investment, policy reform, and freer trade (Francois, Nordström, \& Shiells, 1996; and Strauss \& Ferris, 1996). With such a specification, we expect to capture the dynamic effects of trade reform in the degree of trade openness while simultaneously controlling for the time and type of PTA formation. Furthermore, a dynamic specification also allows determining the speed of adjustment toward the long-run equilibrium relationship between dependent and independent variables.

Thus, a dynamic specification of the model is outlined along the lines of Strauss and Ferris (1996) - based on Phillips and Loretan (1991) — with the corresponding modifications to account for the categorical variables relating to PTA, WTO, and time. Equation (5) provides the basic dynamic specification:

$$
Y_{i, r}=\alpha_{0}+\alpha_{r} X_{i, t}+\alpha_{2} X_{i, r-l}+\alpha_{3} Y_{i, r-l}+\sum_{j=1}^{4} \varphi_{j} P T A_{j i, t}+\omega W T O_{i, t}+\sum_{j=1}^{6} \rho_{j} T_{j}+e_{i, t}
$$

where $X_{l, r}$ is a vector of explanatory variables, and output in time $t$ is now a function of the lagged explanatory variables $X_{t . l}$ and lagged output $Y_{t-l}$. Following Hendry, Pagan, and Sargan (1984), we subtract $Y_{t-1}$ from both sides and rearrange in terms of $X_{t-l}$ to construct an Error Correction $\operatorname{Model}(\mathrm{ECM}):^{?}$

$$
D Y_{i, t}=\beta_{0}+\beta_{l} D X_{i, t}+\beta_{2}\left(Y_{i, t,-1}-\beta_{3} X_{i, t-1}\right)+\sum_{j=1}^{4} \varphi P T A_{j i, t}+\omega W T O_{i, t}+\sum_{j=1}^{6} \rho_{j} T_{j}+e_{i, t}
$$

$D$ represents the difference function, $\beta_{1}$ corresponds to the short-run parameter, $\beta_{3}=1$, and $\beta_{2}$ is defined as the disequilibrium adjustment speed (Hendry et al. 1984). The coefficient $\beta_{2}$ is known as the ECM parameter, or the dynamic component of the productivity and growth model. Wickens and Breusch (1988) argue that in terms of the empirical estimation of the ECM, it is easier to express the model without 
imposing any restriction on the parameters, i.e. $\beta_{3}=I$. Expressing equation (6) in terms of $Y_{i, r}$, results in:

$$
Y_{i, t}=\phi_{I} D Y_{i, t-l}+\theta_{t} X_{i, t}-\gamma D X_{i, t}+\sum_{j=1}^{4} \varphi_{j} P T A_{j i, t}+\omega W T O_{i, t}+\sum_{j=l}^{6} \rho_{j} T_{j}+\mu_{i, t}
$$

In this reformulation, $\phi_{1}$ corresponds to the convergence parameter, i.e., how long it takes to correct the disequilibrium situation; $\theta_{i}$ represents the long-run parameters; and $\gamma_{i}$ represents the short-run estimates. Under (7), the expected parameter sign is $\phi_{1}>0 . \theta_{i}$ and $\gamma_{i}$ follow the same parameter distribution as the corresponding static estimations with labor force having a negative effect on per capita output growth (along steady state situations), capital accumulation affecting positively output growth and trade openness positively influencing output growth. It is expected that long-run coefficients have higher values than corresponding short-run coefficients in absolute terms, if trade openness promotes technological change and development. The effects of PTAs should be reflected as positive coefficients, and once accounted for, the overall effects of trade openness should increase as well; provided that PTAs are both trade creating and consequently growth creating. In this framework of analysis, controlling for the existence of PTAs allows to further decompose the relative contribution of each explanatory variable in both the short and the long runs. Let us assume the case where PTAs promote growth through larger trade openness, then one should expect positive and significant coefficients both from the categorical (PTA) variables and trade openness. On the contrary, if PTA agreements produce diverging effects, then the question becomes whether PTA yields negative and significant coefficients, and how the openness coefficients react to that. We place particular interest in determining the existence of economic differences in magnitude and sign across PTAs coefficients; whether they are bilateral and regional, bilateral and extra regional, multicountry regional (MERCOSUR, CACM, ANDEAN), or multicountry extra regional (MERCOSUR-EFTA), for instance. With these considerations in mind, we proceed to describe the data, estimations, and provide interpretation of the results.

\section{Data and Empirical Analysis}

We obtain the data for this paper from several sources covering 17 Latin American countries (See Tables A1 and A2 in the Appendix for a list of countries 
included in the sample, and Table A3 for corresponding descriptive statistics), for the period 1950-2004. Economic data are from the Penn World Tables 6.2 and include the real GDP per worker PPP Chain (Dependent Variable), population, real capital to output ratio, and real trade openness. While there are several alternative measures of openness, Trade Openness is measured as the ratio of exports plus imports to gross domestic product in constant prices, as it has been done in previous literature. This variable directly measures the amount of trade taking place and its relative importance to each economy's total output; it also makes comparisons across studies more convenient. To adjust the data to the model specification, all economic variables are expressed in natural logarithms, and first-differenced in order to obtain rates of growth. Data for PTAs come from Duran et al. (2007) and Aminian et al. (2008) (see Table A 1); whereas data for WTO accession dates are from Rose (2004).

As indicated earlier, we perform two sets of estimations: one static and one dynamic. For each specification, we estimate a basic productivity model without controlling for PTA (Bilateral-Multicountry and Regional-Extra regional), WTO membership, or decade specific effects. We then expand the model to include the categorical variables. The results of our estimations are reported in Tables 1 and 2 respectively. In this regard, WTO is a dummy variable that takes the value of one at the time of accession to the WTO onwards. PTA is a categorical variable represented in four possible categories, as discussed earlier.

A first look at the descriptive statistics in Table A3 in the appendix reveals some interesting facts. First, we observe that the degree of trade openness is normally distributed across the sample with a Kurtosis of 3.154 and Skewness of 0.07 . Real Gross Domestic Product per worker is marginally leptokurtic and skewed to the left, indicating a high concentration of countries with relatively low income. The Capital-to-output ratio is platykurtic and also skewed to the left. Secondly, information regarding PTAs indicates overwhelming preference across Latin American countries for bilateral-intraregional agreements as the main mechanism to promote trade reform. This type of agreement has become the preferred choice in conjunction with the overall economic reform and liberalization process along the market-driven reforms (see Aminian et al., 2008; Kuwayama et al., 2005; and Krueger, 1999). For instance, there is a maximum of eleven agreements for one country while the average per country is 0.305 agreements. This clearly illustrates the fact that PTAs are concentrated in a few countries that have been more aggressive in their liberalization process, namely Chile and Mexico. On the other hand, Latin American countries have only recently and, therefore, marginally engaged in the implementation of bilateral extra regional agreements, with a maximum of two and an average of only 
Table 1

Pooled LS Economic Growth Estimates with Real GDP per worker PPP chain growth as Dependent Variable for $1951-2003$

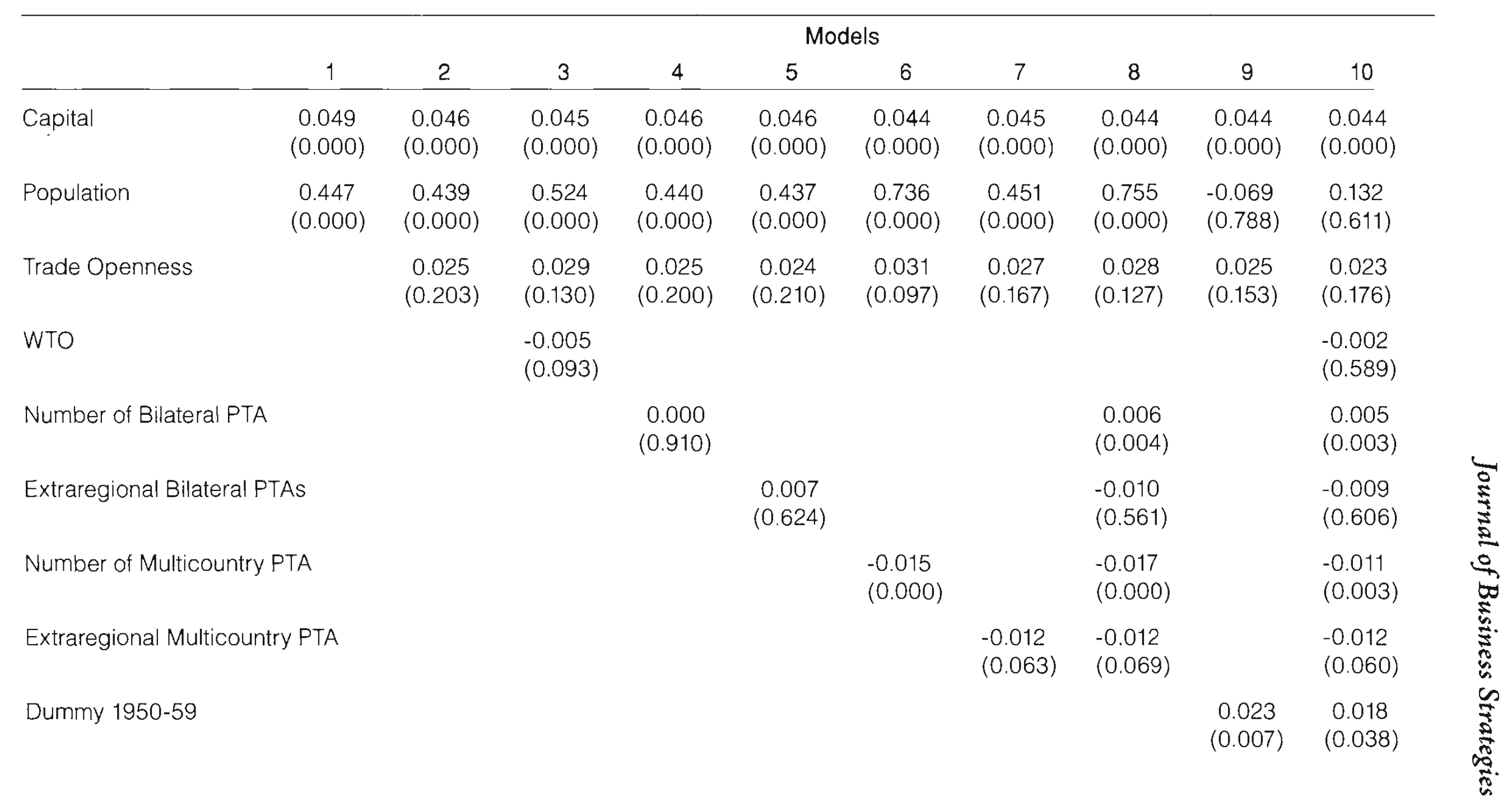


Table 1 (contd.)

Pooled LS Economic Growth Estimates with Real GDP per worker PPP chain growth as Dependent Variable for 1951-2003

\begin{tabular}{|c|c|c|c|c|c|c|c|c|c|c|}
\hline & \multicolumn{10}{|c|}{ Models } \\
\hline & 1 & 2 & 3 & 4 & 5 & 6 & 7 & 8 & 9 & 10 \\
\hline Dummy 1960-69 & & & & & & & & & $\begin{array}{c}0.027 \\
(0.001)\end{array}$ & $\begin{array}{c}0.025 \\
(0.004)\end{array}$ \\
\hline Dummy 1970-79 & & & & & & & & & $\begin{array}{c}0.023 \\
(0.004)\end{array}$ & $\begin{array}{c}0.025 \\
(0.003)\end{array}$ \\
\hline Dummy 1980-89 & & & & & & & & & $\begin{array}{l}-0.012 \\
(0.092)\end{array}$ & $\begin{array}{l}-0.009 \\
(0.238)\end{array}$ \\
\hline Dummy 1990-99 & & & & & & & & & $\begin{array}{c}0.004 \\
(0.544)\end{array}$ & $\begin{array}{c}0.008 \\
(0.384)\end{array}$ \\
\hline Dummy 2000-03 & & & & & & & & & $\begin{array}{l}-0.007 \\
(0.364)\end{array}$ & $\begin{array}{c}0.001 \\
(0.938)\end{array}$ \\
\hline$N^{\circ}$ of obs & 898 & 898 & 898 & 898 & 898 & 898 & 898 & 898 & 898 & 898 \\
\hline $\mathrm{R}^{2}$ & 0.080 & 0.083 & 0.087 & 0.083 & 0.083 & 0.120 & 0.088 & 0.130 & 0.181 & 0.198 \\
\hline
\end{tabular}

No constant reported

Values in parenthesis are $p$-values 
Table 2

ECM with GDP per worker Chain PPP growth as Dependent Variable from 1952-2003

\begin{tabular}{|c|c|c|c|c|c|c|c|c|}
\hline & \multicolumn{8}{|c|}{ Models } \\
\hline & 1 & 2 & 3 & 4 & 5 & 6 & 7 & 8 \\
\hline \multicolumn{9}{|l|}{ Long-run Estimates } \\
\hline Population & $\begin{array}{c}0.439 \\
(0.000)\end{array}$ & $\begin{array}{c}0.532 \\
(0.000)\end{array}$ & $\begin{array}{c}0.440 \\
(0.000)\end{array}$ & $\begin{array}{c}0.438 \\
(0.000)\end{array}$ & $\begin{array}{c}0.745 \\
(0.000)\end{array}$ & $\begin{array}{c}0.453 \\
(0.000)\end{array}$ & $\begin{array}{c}0.797 \\
(0.000)\end{array}$ & $\begin{array}{c}0.218 \\
(0.305)\end{array}$ \\
\hline Capital & $\begin{array}{c}0.063 \\
(0.000)\end{array}$ & $\begin{array}{c}0.060 \\
(0.000)\end{array}$ & $\begin{array}{c}0.063 \\
(0.000)\end{array}$ & $\begin{array}{c}0.063 \\
(0.000)\end{array}$ & $\begin{array}{c}0.058 \\
(0.000)\end{array}$ & $\begin{array}{c}0.061 \\
(0.000)\end{array}$ & $\begin{array}{c}0.057 \\
(0.000)\end{array}$ & $\begin{array}{c}0.056 \\
(0.000)\end{array}$ \\
\hline Trade Openness & $\begin{array}{c}0.028 \\
(0.252)\end{array}$ & $\begin{array}{c}0.038 \\
(0.107)\end{array}$ & $\begin{array}{c}0.028 \\
(0.247)\end{array}$ & $\begin{array}{c}0.028 \\
(0.259)\end{array}$ & $\begin{array}{c}0.042 \\
(0.057)\end{array}$ & $\begin{array}{c}0.031 \\
(0.198)\end{array}$ & $\begin{array}{c}0.037 \\
(0.096)\end{array}$ & $\begin{array}{c}0.028 \\
(0.150)\end{array}$ \\
\hline \multicolumn{9}{|l|}{ Short-run Estimates } \\
\hline Population & $\begin{array}{c}0.697 \\
(0.170)\end{array}$ & $\begin{array}{c}0.559 \\
(0.267)\end{array}$ & $\begin{array}{c}0.693 \\
(0.171)\end{array}$ & $\begin{array}{c}0.702 \\
(0.167)\end{array}$ & $\begin{array}{c}0.235 \\
(0.635)\end{array}$ & $\begin{array}{c}0.644 \\
(0.203)\end{array}$ & $\begin{array}{c}0.254 \\
(0.605)\end{array}$ & $\begin{array}{c}0.521 \\
(0.280)\end{array}$ \\
\hline Capital & $\begin{array}{l}-0.036 \\
(0.000)\end{array}$ & $\begin{array}{l}-0.034 \\
(0.000)\end{array}$ & $\begin{array}{l}-0.036 \\
(0.000)\end{array}$ & $\begin{array}{l}-0.036 \\
(0.000)\end{array}$ & $\begin{array}{l}-0.033 \\
(0.000)\end{array}$ & $\begin{array}{l}-0.035 \\
(0.000)\end{array}$ & $\begin{array}{l}-0.033 \\
(0.000)\end{array}$ & $\begin{array}{l}-0.031 \\
(0.000)\end{array}$ \\
\hline Trade Openness & $\begin{array}{l}-0.028 \\
(0.090)\end{array}$ & $\begin{array}{l}-0.033 \\
(0.039)\end{array}$ & $\begin{array}{l}-0.028 \\
(0.088)\end{array}$ & $\begin{array}{l}-0.028 \\
(0.092)\end{array}$ & $\begin{array}{l}-0.035 \\
(0.020)\end{array}$ & $\begin{array}{l}-0.028 \\
(0.079)\end{array}$ & $\begin{array}{l}-0.031 \\
(0.041)\end{array}$ & $\begin{array}{l}-0.027 \\
(0.048)\end{array}$ \\
\hline ECM-Dynamic & $\begin{array}{c}0.485 \\
(0.000)\end{array}$ & $\begin{array}{c}0.485 \\
(0.000)\end{array}$ & $\begin{array}{c}0.485 \\
(0.000)\end{array}$ & $\begin{array}{c}0.485 \\
(0.000)\end{array}$ & $\begin{array}{c}0.487 \\
(0.000)\end{array}$ & $\begin{array}{c}0.487 \\
(0.000)\end{array}$ & $\begin{array}{c}0.490 \\
(0.000)\end{array}$ & $\begin{array}{c}0.487 \\
(0.000)\end{array}$ \\
\hline WTO & & $\begin{array}{l}-0.006 \\
(0.026)\end{array}$ & & & & & $\begin{array}{l}-0.003 \\
(0.222)\end{array}$ & $\begin{array}{l}-0.002 \\
(0.505)\end{array}$ \\
\hline Number of Bilateral PTA & & & $\begin{array}{c}0.000 \\
(0.922)\end{array}$ & & & & $\begin{array}{c}0.007 \\
(0.000)\end{array}$ & $\begin{array}{c}0.007 \\
(0.000)\end{array}$ \\
\hline Extraregional Bilateral PTA & & & & $\begin{array}{c}0.006 \\
(0.619)\end{array}$ & & & $\begin{array}{l}-0.015 \\
(0.231)\end{array}$ & $\begin{array}{l}-0.015 \\
(0.243)\end{array}$ \\
\hline
\end{tabular}


Table 2 (contd.)

ECM with GDP per worker Chain PPP growth as Dependent Variable from 1952-2003

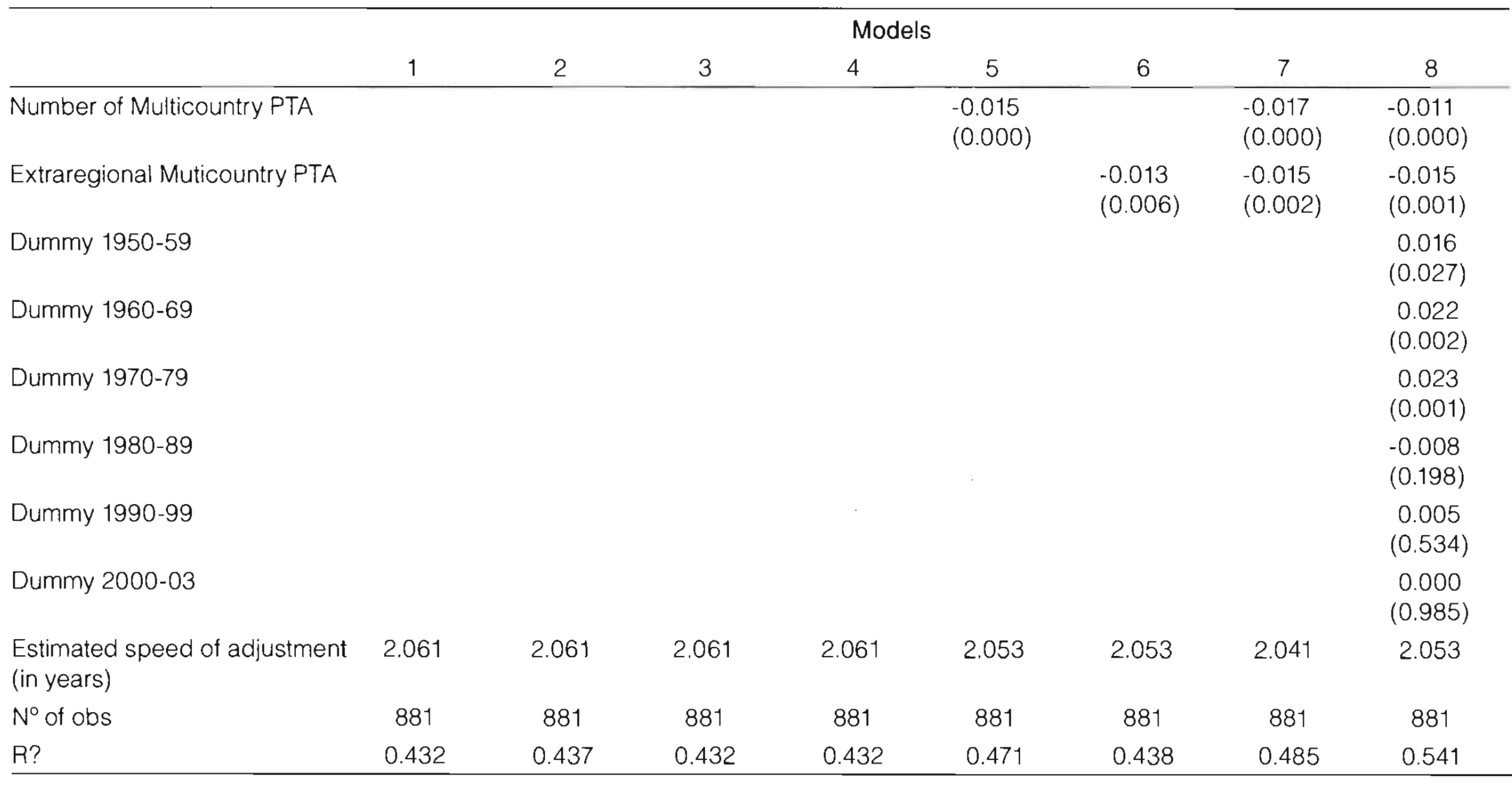

No constant reported

Values in parenthesis are $p$-values 
0.01 trade agreements per country. Thirdly, multicountry agreements are less common for a variety of reasons such as a required higher number of countries involved, higher administrative cost and greater complexity of coordination (diseconomies of scale). In this regard, we observe an average of 0.53 intraregional agreements over 0.046 extraregional agreements per country. It is relevant to point out that the largest intraregional multicountry agreements were signed both in the context of the ISI process during the 1960s and with geographical proximity consideration in mind included countries that share common borders, like in the case of CACM and ANDEAN. MERCOSUR shares these same characteristics but was signed in 1991. Finally, extraregional multicountry agreements have appeared most recently during the 1990s and 2000s, as a response to halted multilateral negotiations, such as the Doha Round, as mentioned earlier. This newest wave of PTAs is slightly different from the previous ones as they now incorporate countries that do not necessarily have common borders.

\section{Findings}

The results from the static and dynamic estimations are presented in Tables 1 and 2 , respectively. We make the following observations from the static model estimation results. First, the evidence confirms the null hypothesis that trade enhances growth. However, while the relationship is positive, it is statistically significant only after controlling for some categorical elements. For example, when controlling for membership to the WTO, trade openness is positive but not statistically significant. Furthermore the WTO coefficient is both negative and significant at the $10 \%$ in estimation 3 but not in estimation 10 (See Table 1). This result concurs with those reported by Rose (2004, p.98). One common problem with model specifications such as the one used in this paper is the issue of endogeneity. In particular, trade openness could be endogenous to output growth. To check for the presence of endogeneity, we conduct the Durbin-Wu-Hausman test and do not find supporting evidence to reject the null hypothesis of no endogeneity. ${ }^{8}$

We then proceed to control for the effects of PTAs on output growth and observe two interesting results: a) the coefficient for trade openness increases or remains the same in magnitude and its statistical significance increases as we include the categorical variables for PTAs; and b) the coefficients for all PTAs control variables are negative and statistically significant in case of multicountry PTAs while they are either significantly positive or negative and statistically insignificant in case of bilateral regional PTAs. Thus, our empirical evidence clearly indicates that mul- 
Table 3

Pooled LS Ceteris Non Paribus Economic Growth Estimates with

Real GDP per worker PPP chain growth as Dependent Variable for 1951-2003

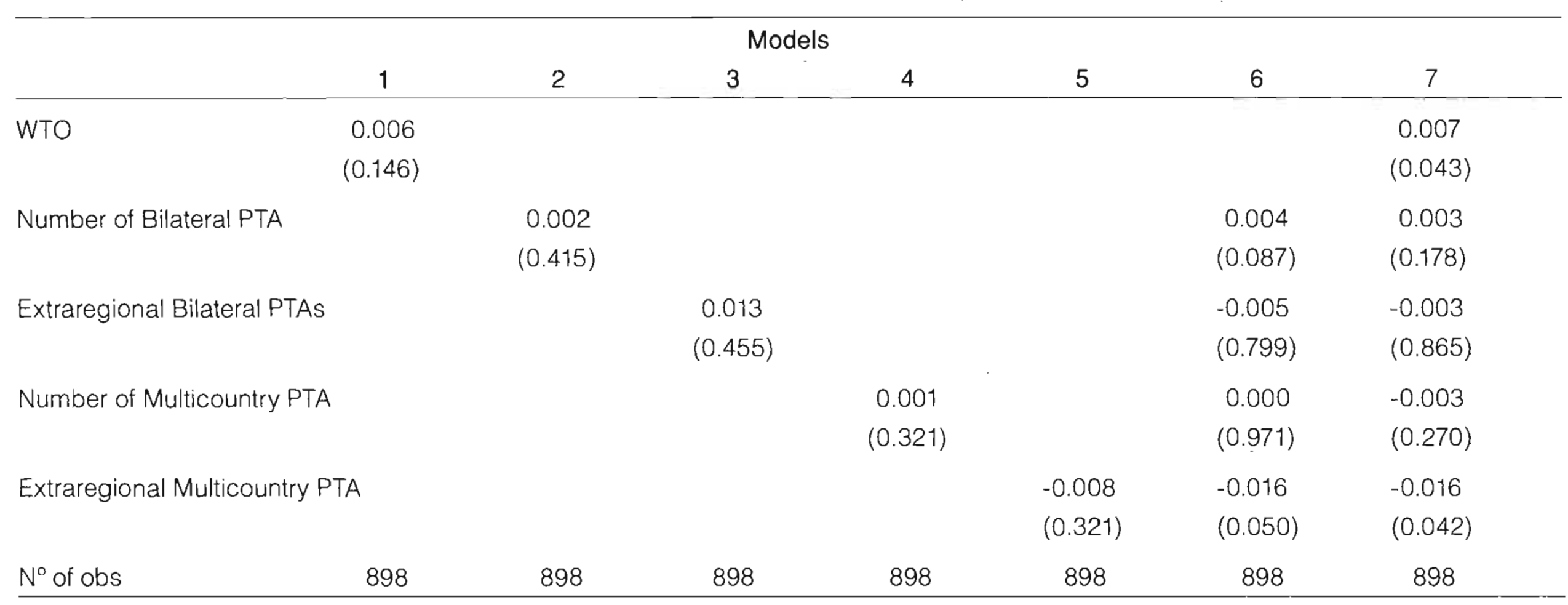

No constant reported

values in parenthesis are $p$-values 
ticountry PTAs are not growth-creating but growth-diverting. When controlling for the presence of PTAs we observe an increase in the magnitude of coefficient of trade openness. This seems to indicate that trade openness reduces the negative effect of PTAs in the allocation of resources in most cases. This is to say that increases in trade openness resulting through markets - de facto - are growth enhancing, confirming our null hypothesis. In support of these results, we note that Krueger (1999) provides evidence indicating that MERCOSUR has greater potential for trade diversion; while Kuwayama et al. (2005) find that trade liberalization in Latin America shows no real evidence of output growth acceleration. Finally, the decade-dummy variables have positive signs with the exception of the lost decade of the $1980 \mathrm{~s}$, as expected.

The dynamic results in Table 2 yield the same basic conclusions as the static ones do. However, the new estimations allow to decompose effects into short-run and long-run, while adding a dynamic speed of adjustment parameter. The dynamic specification increases overall explanatory power as indicated by consistently higher $\mathbf{R}^{2}$ values. Our estimates for the ECM parameter are consistent across model specifications with a value of 0.48 and statistically significant at the $1 \%$ level, indicating that it takes a little over 2 years for any deviation from the long term equilibrium relationship to dissipate.

Several aspects of the dynamic estimations are worth mentioning. First, longrun estimates for trade openness are greater than the corresponding short-run. This result indicates that there are significant long term implications of trade openness on output growth as economies in the region are able to derive positive effects in the form of technological development and/or transfer. Nevertheless, the long-run positive gains from trade are obscured by short term losses, as the short term coefficients are negative in magnitude and statistically significant. This result becomes more obvious when the coefficients for PTAs are either negative and statistically significant or positive but statistically insignificant. Only bilateral preferential agreements are positive and significant, when controlling for all other categorical variables. To add to the robustness of the results, we observe that when controlling for the presence of preferential trade agreements, not only are long-run trade coefficients larger than corresponding short-run, but more importantly, long-run trade coefficients increase in magnitude compared to the Model 1 with no controls in Table 2. This is an interesting new result as the evidence appears to indicate that while PTAs may result in increased trade among agreement members, this comes at the expense of economic growth from trade with nonmembers. Yeats (1997) provides concurrent proof indicating that industrial policy within RTAs is distortionary for resource allocation. In a 
way, PTAs create a raise to the bottom, as they appear to create immiserizing growth. Our results seem to confirm this argumentation.

Further analysis of the separation of effects under the dynamic estimation reveals another interesting result. The fact that the short term coefficients are negative and larger in magnitude (larger in negative terms) when controlling for PTA (which are negative), is an indication that short term trade openness is driving economies away from allocating resources according to comparative advantages. Partial protectionism in the form of PTAs results in trade diversion and relative inefficient resource allocation. Despite being a puzzling scenario, one can bring forth the argument that PTAs may be creating pervasive incentives for firms to sell to (and buy from) PTA members when otherwise would not be economically efficient under market conditions. Thus, the evidence overwhelmingly indicates that PTAs are diverting trade, and more importantly, resulting in economic growth diversion from long term sustainable growth to short term cash flow away from comparative advantage allocation of resources. Based on these results, we neither find support to the hypothesis that PTAs are growth creating, nor find evidence supporting the fact that PTAs increase trade openness along the lines of comparative advantage. It is only after we control for PTAs that we observe an increase in the long-run trade openness effect on output growth. This is to say that trade outside PTAs seems to be more relevant for sustained per capita output growth in the long-run. Clearly integration via de facto creates growth, while integration via de jure appears to divert growth. We acknowledge that more empirical evidence is needed to fully confirm these results.

To further explore the role of PTAs and WTO membership on output growth we conducted a third separate set of estimations, with only control variables and no factors of production (trade openness included). The results are reported in Table 3 under the name of ceteris non paribus estimations. The idea behind this estimation is to determine what happens when we isolate the effect of categorical variables on output growth. The results, once again, are not encouraging for WTO membership and PTAs. The coefficients for the WTO are now positive and statistically significant at the $15 \%$ level with no other controls and at the $4 \%$ level when all PTAs are included. This is to say that WTO creates growth only under ceteris non paribus conditions. PTA coefficients are not statistically significant or have a negative sign, with the exception of Bilateral PTAs that are positive and statistically significant when combined with other types of PTAs. On the positive side, this new set of estimates provides further evidence of the robustness of the previous Pooled LS and ECM estimations. 
Table 4

Pooled LS Estimates with Trade Openness growth as Dependent Variable for 1951-2004

\begin{tabular}{|c|c|c|c|c|c|c|}
\hline \multicolumn{7}{|c|}{ Models } \\
\hline & 1 & 2 & 3 & 4 & 5 & 6 \\
\hline \multirow[t]{2}{*}{ WTO } & 0.020 & & & & & 0.016 \\
\hline & $(0.002)$ & & & & & $(0.010)$ \\
\hline \multirow[t]{2}{*}{ Number of Bilateral PTA } & & 0.008 & & & & 0.003 \\
\hline & & $(0.006)$ & & & & $(0.477)$ \\
\hline \multirow[t]{2}{*}{ Extraregional Bilateral PTAs } & & & 0.029 & & & 0.004 \\
\hline & & & $(0.062)$ & & & $(0.833)$ \\
\hline \multirow[t]{2}{*}{ Number of Multicountry PTA } & & & & 0.013 & & 0.002 \\
\hline & & & & $(0.020)$ & & $(0.732)$ \\
\hline \multirow[t]{2}{*}{ Extraregional Multicountry PTA } & & & & & 0.022 & 0.005 \\
\hline & & & & & $(0.071)$ & $(0.710)$ \\
\hline$N^{\circ}$ of obs & 907 & 907 & 907 & 907 & 907 & 907 \\
\hline
\end{tabular}

No constant reported

values in parenthesis are p-values 
So far our results have uncovered that trade openness leads to faster growth, confirming the theoretical work outlined earlier in the paper. More importantly, the ECM estimations indicate that the long-run effects are positive and higher than their short-run counterparts, supporting the hypothesis that technology transfers facilitated by trade openness are more important than gains associated with static comparative advantages. This result becomes more relevant as it confirms Yeats' (1997) findings for MERCOSUR showing a major re-orientation of exports toward regional markets. Based on the negative short term parameter estimates, it is possible to argue that some of this export reorientation has not been along the comparative advantage patterns. It is possible that while regional agreement members do export along the comparative advantage lines to non-member markets, this possible positive effect on economic growth is more than offset by the potential misallocation of resources that results from serving the regional market under PTA agreement. At the same time, WTO membership and PTAs categorical variables display negative effects on growth or are not-statistically significant.

There is, however, one more question that still remains unanswered. What are the effects of the categorical variables on trade openness? Results from Table 1 and particularly Table 2, indicate that when controlling for WTO membership and PTAs, the positive effect of trade openness on output growth increases while categorical variables have negative or statistically insignificant coefficients in most cases. However, in order to gain more insights into the relationship between categorical variables and trade openness, we add one more set of estimations, where the rate of growth of trade openness is now the dependent variable. The results of these estimations are reported in Table 4. Individual estimations indicate that each of the categorical variables has a positive effect on trade openness at the $7 \%$ confidence level. When estimated together, only WTO membership has a positive and statistically significant effect on trade openness growth, while the rest of the controls become statistically insignificant. Rose (2004, p.111) finds similar results and notes that "GATT/WTO seems to have a huge effect on trade if one does not hold other things constant; the multilateral trade regime matters, ceteris non paribus." These findings seem to imply that membership to preferential trade agreements and WTO results in increased trade openness, but this positive effect does not translate into faster economic growth. Faster trade openness growth is then the result of more trade among preferential agreement members at the expense of non-members. This, combined with the fact that output per worker does not grow faster when controlling for PTAs and WTO, indicates that the increased trade resulting from PTA membership is diverting in nature. Since memberships to PTAs and WTO have positive 
effects on trade openness growth (Table 4), we proceed to re-estimate the output growth model in a two-stage process. ${ }^{9}$ We first extract the residuals from estimations in Table 4, and then include them in the growth equations with PTAs and WTO categorical variables, in the hope that the residuals would have economic and statistical significance. However, these alternative estimations yield almost identical results to those already reported in Tables 1 and 2 .

The results from the different sets of estimations then raise the question: why are PTAs not positively related to output growth, even when they may have resulted in weak increased trade openness? Several explanations are provided. While not all of them may apply directly or they are simply beyond the scope of our study, we present them here for clarification and illustration purposes. First, Krueger (1999 p. 115) sheds some light by indicating that "the welfare effects for the countries within the preferential agreement are ambiguous." Another possible explanation for the controversial nature of these results is found in Duran et al. (2008), as they indicate that "Latin America growth was low and volatile, the exchange rate overvalued during long periods, and inflation and interest rates high." (p.39). In addition, Soloaga and Winters (1999), in regards to MERCOSUR, argue "trade performance was dominated by currency overvaluation rather than trade policy" (p. 11). Finally, Yeats (1997) indicates "products recording the largest shift toward the region are those for which Mercosur has not demonstrated an ability to export competitively elsewhere" (p.20).

\section{Conclusions and Recommendations}

Empirical analysis of the effects of PTAs and GATT/WTO membership on output growth using static and dynamic growth estimations is inconclusive. The results of this paper strongly suggest that trade reform based on the proliferation of PTAs does not yield the expected positive results on output growth. This is true for Latin American countries engaging in PTAs. While further research is desirable, the evidence so far points to important policy implications. First, PTAs in Latin America appear to be dominated by trade diversion effects; and secondly, the proliferation of PTAs creates an adverse effect on long-run per capita output growth. In other words, PTAs create an economic growth diversion effect, moving economies away from efficient long term resource allocation. The redirection of trade resulting from preferential ruling among agreement members results, albeit weakly, in more trade openness; yet at the expense of faster economic growth. This result is puzzling and could be controversial.

The decomposition of the effects into short-run and long-run under the ECM model provides a more comprehensive set of effects that are not present under the con- 
ventional static model. In this regard, the dynamic results indicate a significant larger positive effect of trade openness on output growth in the long-run over the short-run. These results are more interesting after controlling for PTAs and GATT/WTO membership, given that the long-run parameters increase in magnitude and significance, while categorical variables have negative or statistically insignificant effects on per capita output growth. Further analysis of the data indicates the presence of a weak positive effect of PTAs and GATT/WTO membership on output growth ceteris non paribus. That is, only when we do not control for capital, labor, and degree of trade openness, we observe the hypothesized positive effect of integration via de jure.

The implications of these results in terms of policy analysis and future research are vast. First, has Latin America followed the wrong path (a race to the bottom) by promoting integration via de jure? Or, are there other forces such as exchange rate overvaluation, economy-wide financial crisis, PTAs intrinsic design conflicts, for instance, offsetting the likelihood of positive effects that could be derived from integration a la PTA? Either way, it is clear that further research on the role of PTAs on output growth is real and necessary.

Undoubtedly, our results signify the need for further research when attempting to assess the nature and corresponding output growth effects of PTAs and WTO (multilateral) membership. Other relevant areas of research outside the scope of this current paper include the role that institutional factors may play in the reform process as they relate to exchange rate regimes, inflationary processes, the role of democracy, geography and other issues addressed in the literature. Finally, another interesting avenue for future research is to analyze the relative importance of each PTA as they relate to different countries and therefore could potentially have country specific effects on participating countries.

\section{Notes}

1. We thank comments from participants at the Regional Trade Agreements, Migration and Remittances Conference at Sam Houston State University, 2008; and participants at the AEA Pipeline Conference at the University of Santa Barbara 2008. We gratefully acknowledge the contributions of two anonymous referees, and funding provided through the College of Business Summer Research Grants at Clarion University to complete this research. Any remaining errors are the sole responsibility of the authors.

2. Aminian, Fung, and $\mathrm{Ng}$ (2008) refer to this as the first stage of preferential trade agreements within the context of Import Substitution Industrialization. 
3. See Ben-David and Loewy( 1998); Keller (2002); Grossman and Helpman (1991); Harrison (1996); Aghion and Howitt (1998); Edwards (1993); and Romer (1990); among others.

4. See Balassa (1978); Barboza (2007); Mbaku (1989); Kavoussi (1984); Tyler (1981); Moschos (1989); De Gregorio (1992); Ram (1985); Edwards (1992, 1993); Harrison (1996); among many others.

5. A detailed summary of the evolution of the trade agreements in Latin America is available in Table A2.

6. See Barboza 2007, Ram 1985; Feder 1982; and Mbaku 1989; among others

7. See Barboza (2007) for further details.

8. The results of the endogeneity test are available from the authors upon request.

9. We thank an anonymous referee for this suggestion.

\section{References}

Aghion, P., \& Howitt, P. (1998), Endogenous growth theory. The MIT Press.

Aminian, N., Fung, K.C., \& Ng, F. (2008, March). Integration of markets vs. integration by agreements. Policy Research Working Paper WPS 4546. The World Bank.

Balassa, B. (1978). Exports and economic growth: Further evidence. Journal of Development Economics, 5, 181-189.

Barboza, G. (2007). Dynamic empirics of trade openness and economic growth in Latin America. Does fast reformers grow faster? Journal of Economic Development, 32(2), 1-20.

Ben-David, D., \& Loewy, M. (1998). Free trade, growth and convergence. Journal of Economic Growth, 3, 143-170.

Cardoso, E., \& Helwege, A. (1995). Latin America's economy. The MIT Press.

Carvalho, A., et. al. (1999). Impactos da integracao comercial Brasil - Estados Unidos. Texto para Discussao (No 646). Rio de Janeiro: IPEA.

Chang, W., \& Winters, L.A. (Sep., 2002). How regional blocks affect excluded countries: The price effects of MERCOSUR. The American Economic Review, 92(4), 899-904.

De Gregorio, J. (1992). Economic growth in Latin America. Journal of Development Economics, 39, 59-84. 
Dowrick, S., \& Golley, J. (2004). Trade openness and growth: Who benefits? Oxford Review of Economic Policy, 20(1), 38-56.

Duran Lima, J., Mulder, N., \& Onodera, O. (2008, February). Trade liberalization and economic performance: East-Asia versus Latin America. OECD Trade Policy Working Paper No. 170.

Duran Lima, J., De Miguel, C. J., \& Schuschny, A. (2007, February). Acuerdos comerciales entre los paises andinos y los Estados Unidos. Cuanto se puede esperar de ellos? Serie Comercio Internacional (77). Cepal.

Edwards, S. (1993). Openness, trade liberalization, and growth in developing countries. Journal of Economic Literature, XXXI, 1358-1393.

Edwards, S. (1992). Trade orientation, distortions and growth in developing countries. Journal of Development Economics, 39, 31-57.

Fauriol, G., \& Weintraub, S. (2001). The century of the Americas: Dawn of a new century dynamic. The Washington Quarterly, 24(2), 139-148.

Feder, G. (1982). On exports and economic growth. Journal of Development Economics, 12, 59-73.

Foroutan, F. (1998, March) Does membership in a regional preferential trade agreement make a country more or less protectionist? Policy Research Working Paper, The World Bank.

Francois, J., Nordström, H., \& Shiells, C. (1996). Transition dynamics and trade policy reform in developing countries. World Trade Organization, RD-96-005.

Gouvea, R., \& Hranaiova, J. (2002). Brazil and the FTAA: Strategic trade options. Multinational Business Review, 33-41.

Grossman, G., \& Helpman, E. (1990). Comparative advantage and long-run growth. The American Economic Review, 80(4), 796-815.

Grossman, G., \& Helpman, E. (1991). Trade, knowledge spillovers and growth. European Economic Review, 35, 517-526.

Grossman, G., \& Helpman, E. (1994). Endogenous innovation in the theory of growth. Journal of Economic Perspectives, 8(1), 23-44.

Hendry, D., Pagan, A., \& Sargan, J. (1984). Dynamic Specification. In Z. Grichles \& M. Intrilagator (Eds.), Handbook of Econometrics, (pp. 1689-1763).

Jurn, I., \& Park, H. (2002). The trade effects on the non-member countries of the regional integration: The case of the Mercosur. Multinational Business Review, 23-32.

Kavoussi, R. M. (1984). Export expansion and economic growth: Further empirical evidence. Journal of Development Economics, 14, 241-250. 
Keller, W. (2002). Trade and the transmission of technology. Journal of Economic Growth, 7, 5-24.

Knight, M., Loayza, N., \& Villanueva, D. (1993). Testing the neoclassical theory of economic growth: A panel data approach. IMF Staff Papers International Monetary Fund, (40), 512-541.

Krueger, A. (1999, Fall). Are preferential trade arrangements trade-liberalizing or protectionist? Journal of Economic Perspectives, 13(4), 105-124.

Kuwayama, M., Duran, J., \& Silva, V. (2005, December). Bilateralism and regionalism: Re-establishing the primacy of multilateralism a Latin American and Caribbean perspective. Serie Comercio Internacional (58). CEPAL.

Mankiw, G., Romer, D., \& Weil, D. (1992). A contribution to the empirics of economic growth. Quarterly Journal of Economics, 107, 407-437.

Mbaku, J. M. (1989). Export growth and economic performance in developing countries : Further evidence from Africa. Journal of Economic Development, 14, 127-142.

Moran, C. (1983). Export fluctuations and economic growth: An empirical analysis. Journal of Development Economics, 12, 195-218.

Moschos, D. (1989). Export expansion, growth and the level of economic development: An empirical analysis. Journal of Development Economics, 30, 93-102.

Penn World Tables Mark 6.2.

Phillips, P., \& Loretan, M. (1991). Estimating long-run economics equilibria. Review of Economic Studies, 58, 407-436.

Ram, R. (1985). Exports and economic growth: Some additional evidence. Economic Development and Cultural Change, 33, 415-425.

Romer, P. (1986). Increasing returns and long-run growth. Journal of Political Economy, 94(5), 1002-1037.

Romer, P. (1990). Endogenous technological change. Journal of Political Economy, 98(5-2), S71-S102.

Romer, P. (1994). The origins of endogenous growth. Journal of Economic Perspectives, 8(1), 3-22.

Rose, A. (2004, March). Does the WTO really increase trade? The American Economic Review, 94(1), 98-114.

Saggi, K., \& Yildiz, H. (2008). Bilateralism, multilateralism, and the quest for global free trade. Manuscript.

Soloaga, I., \& Winters, L.A. (1999, August) How has regionalism in the 1990s affected trade? Policy Research Working Paper 2156, The World Bank. 
Solow, R. (1957). Technical change and the aggregate production function. Review of Economics and Statistics, 39, 312-320.

Strauss, J., \& Ferris, M. (1996). A dynamic estimation of world productivity growth. Applied Economics, 28, 195-202.

Tyler, W. G. (1981). Growth and export expansion in developing countries: Some empirical evidence. Journal of Development Economics, 9, 121-130.

Wickens, M., \& Breusch, T. (1988). Dynamic specification, the long-run and the estimation of transformed regression models. Economic Journal, 98, 189-205.

Yeats, A. (1997, February). Does Mercosur's trade performance raise concerns about the effects of regional trade agreements? Policy Research Working Paper, The World Bank.

\section{$\overline{\text { Appendix }}$}

Table A1

Latin American Countries and year of accession to the World Trade Organization

\begin{tabular}{cc}
\hline Country & Year \\
\hline Argentina & 1967 \\
Bolivia & 1990 \\
Brazil & 1948 \\
Chile & 1949 \\
Colombia & 1981 \\
Costa Rica & 1990 \\
Ecuador & 1996 \\
El Salvador & 1991 \\
Guatemala & 1991 \\
Honduras & 1994 \\
Mexico & 1986 \\
Nicaragua & 1950 \\
Panama & 1997 \\
Paraguay & 1994 \\
Peru & 1951 \\
Uruguay & 1953 \\
Venezuela & 1990 \\
\hline
\end{tabular}

Source: Selected countries form Rose, Andrew (2004) American Economic Review. 94.1. p 113. 
Table A2

Economic Cooperative Agreements in Latin America

\begin{tabular}{|c|c|c|c|}
\hline & Year of inforce & Type of agreement & Status \\
\hline \multicolumn{4}{|l|}{ Bilateral Agreements } \\
\hline \multicolumn{4}{|l|}{ Regional } \\
\hline Chile-Argentina & 1991 & Econ Integration Agreement & Implemented \\
\hline Mexico-Argentina & 1991 & Econ Integration Agreement EIA and Free Trade & Implemented \\
\hline Chile-Mexico & $1992 / 98$ & Agreement & Implemented \\
\hline Chile-Bolivia & 1993 & Econ Integration Agreement & Implemented \\
\hline Chile-Venezuela & 1993 & Econ Integration Agreement & Implemented \\
\hline Chile-Colombia & 1994 & Econ Integration Agreement EIA and Free Trade & Implemented \\
\hline Mexico-Bolivia & $1994 / 95$ & Agreement & Implemented \\
\hline Chile-Ecuador & 1995 & Econ Integration Agreement & Implemented \\
\hline Mexico-Costa Rica & 1995 & Free Trade Agreement & Implemented \\
\hline Mexico-Peru & 1996 & Econ Integration Agreement & Implemented \\
\hline Mexico-Nicaragua & 1998 & Free Trade Agreement & Implemented \\
\hline Chile-Peru & 1998 & Econ Integration Agreement & Implemented \\
\hline Mexico-El Salvador & 2001 & Econ Integration Agreement & Implemented \\
\hline Mexico-Guatemala & 2001 & Free Trade Agreement & Implemented \\
\hline Mexico-Honduras & 2001 & Free Trade Agreement & Implemented \\
\hline Mexico- Brazil & 2002 & Econ Integration Agreement & Signed \\
\hline Chile-Costa Rica & 2002 & Free Trade Agreement & Implemented \\
\hline Chile-EI Salvador & 2002 & Econ Integration Agreement & Implemented \\
\hline
\end{tabular}


Table A2 (cont'd.)

Economic Cooperative Agreements in Latin America

\begin{tabular}{|c|c|c|c|}
\hline & Year of inforce & Type of agreement & Status \\
\hline Mexico-Uruguay & 2003 & Free Trade Agreement & Signed \\
\hline El Salvador-Panama & 2003 & Free Trade Agreement & Signed \\
\hline \multicolumn{4}{|l|}{ Extra Regional } \\
\hline Chile-Canada & 1997 & Free Trade Agreement & Implemented \\
\hline Mexico-Israel & 2000 & Free Trade Agreement & Implemented \\
\hline Costa Rica- Canada & 2002 & Free Trade Agreement & Signed \\
\hline Chile-Korea & 2003 & Free Trade Agreement & Signed \\
\hline Chile-United States & 2004 & Econ Integration Agreement & Signed \\
\hline \multicolumn{4}{|l|}{ Multi-Countries Agreements } \\
\hline \multicolumn{4}{|l|}{ Regional } \\
\hline \multicolumn{4}{|l|}{ CACM (Costa Rica,El Salvador, Guatemala, } \\
\hline Honduras) & 1961 & Customs Union & Implemented \\
\hline CARICOM (incl. 15 Caribbean countries) & $1973 / 97$ & Customs Union and EIA & Implemented \\
\hline \multicolumn{4}{|c|}{ LAIA (Argentina, Bolivia, Brazil, Chile, Colombia, } \\
\hline \multicolumn{4}{|l|}{ Cuba, Equador, Mexico, Paraguay, Peru, } \\
\hline Venezuela) & 1981 & Partial Scope & Implemented \\
\hline \multicolumn{4}{|l|}{ ANDEAN (Bolivia, Colombia, Ecuador, Peru } \\
\hline Venezuela) & 1969 & Custom Union & Implemented \\
\hline \multicolumn{4}{|l|}{ MERCOSUR (Argentina, Brazil, Paraguay, } \\
\hline Uruguay, Venezuela joined 2006) & $1991 / 05$ & Customs Union & Implemented \\
\hline
\end{tabular}


Table A2 (cont'd.)

Economic Cooperative Agreements in Latin America

\begin{tabular}{|c|c|c|c|}
\hline Ye & of inforce & Type of agreement & Status \\
\hline G3 (Colombia, Mexico, Venezuela) & 1995 & Free Trade Agreement & Implemented \\
\hline Chile- MERCOSUR & 1996 & Econ Integration Agreement & Implemented \\
\hline Bolivia-MERCOSUR & 1997 & Econ Integration Agreement & Implemented \\
\hline Mexico- Central America & 2001 & Free Trade Agreement & Implemented \\
\hline Mexico- MERCOSUR & 2002 & Econ Integration Agreement & Signed \\
\hline Peru-MERCOSUR & 2003 & Econ Integration Agreement & Signed \\
\hline \multicolumn{4}{|l|}{ Extrarregional } \\
\hline NAFTA (Canada, Mexico, United States) & 1994 & Econ Integration Agreement & Implemented \\
\hline MERCOSUR- European Countries & 1999 & Cooperative Agreement & Implemented \\
\hline Mexico-European Communities & 2000 & Econ Integration Agreement & Implemented \\
\hline Mexico-EFTA & 2001 & Free Trade Agreement & Implemented \\
\hline Chile- European Communities & 2003 & Free Trade Agreement & Signed \\
\hline MERCOSUR-India & 2003 & Econ Integration Agreement & Signed \\
\hline Chile- EFTA & 2004 & Econ Integration Agreement & Signed \\
\hline Dominican Rep.- Central America- United States & 2006 & Free Trade Agreement & Signed \\
\hline
\end{tabular}

Sources: Aminian, Nathalie, K.C. Fung and F. Ng. Integration of Markets vs. Integration by Agreements. Policy Research Working Paper 4546 World Bank. March 2008 p.15-16, \& Duran, José et al. (2007) Acuerdos Comerciales entre los países andinos y los Estados Unidos. Cuánto se puede esperar de ellos? Serie Comercio Internacional 77, CEPAL. 
Table A3

Descriptive Statistics for 17 Latin American Countries 1950-2004

\begin{tabular}{|c|c|c|c|c|c|c|c|c|c|}
\hline & \multirow[b]{2}{*}{ Population } & \multicolumn{2}{|c|}{ tural Logarithm } & \multirow[b]{2}{*}{$\begin{array}{l}\text { Real GDP } \\
\text { per worker }\end{array}$} & \multirow[b]{2}{*}{$\begin{array}{c}\text { WTO } \\
\text { Membership }\end{array}$} & Bilateral PTAs & \multicolumn{3}{|c|}{ MultiCountry PTAs } \\
\hline & & $\begin{array}{c}\text { Real } \\
\text { Capital/ } \\
\text { Output }\end{array}$ & $\begin{array}{c}\text { Real } \\
\text { Trade } \\
\text { Openness }\end{array}$ & & & Regional & $\begin{array}{c}\text { Extra } \\
\text { Regional }\end{array}$ & Regional & $\begin{array}{c}\text { Extra } \\
\text { Regional }\end{array}$ \\
\hline Mean & 8.968 & 2.551 & 3.596 & 9.433 & 0.487 & 0.305 & 0.011 & 0.536 & 0.046 \\
\hline Median & 8.720 & 2.572 & 3.608 & 9.500 & 0 & 0 & 0 & 1 & 0 \\
\hline Maximum & 12.112 & 3.820 & 5.368 & 10.307 & 1 & 11 & 2 & 3 & 3 \\
\hline Minimum & 6.765 & -1.656 & 1.882 & 8.371 & 0 & 0 & 0 & 0 & 0 \\
\hline Std. Dev. & 1.236 & 0.502 & 0.686 & 0.439 & 0.500 & 1.107 & 0.114 & 0.567 & 0.273 \\
\hline Skewness & 0.574 & -0.649 & 0.070 & -0.202 & 0.050 & 5.668 & 11.515 & 0.528 & 7.246 \\
\hline Kurtosis & 2.572 & 7.521 & 3.154 & 2.158 & 1.003 & 40.576 & 150.845 & 2.712 & 63.273 \\
\hline Jarque-Bera & 57.302 & 843.544 & 1.657 & 33.295 & 152.50 & 58728.70 & 853564 & 45.66 & 146510 \\
\hline Probability & 0.000 & 0.000 & 0,437 & 0.000 & 0 & 0 & 0 & 0 & 0 \\
\hline Sum & 8205.51 & 2334.52 & 3290.57 & 8631.59 & 446 & 279 & 10 & 490 & 42 \\
\hline Sum Sq. Dev. & 1397.10 & 230.39 & 430.11 & 175.97 & 228.61 & 1119.92 & 11.89 & 293.59 & 68.07 \\
\hline Observations & 915 & 915 & 915 & 915 & 915 & 915 & 915 & 915 & 915 \\
\hline Cross sections & 17 & 17 & 17 & 17 & 17 & 17 & 17 & 17 & 17 \\
\hline
\end{tabular}

Data from the Penn World Tables 6.2, Rose (2004), Aminian et.al (2008), \& Duran et al (2007). 


\section{Biographical Sketch of Authors}

Gustavo A Barboza is an Associate Professor of Administrative Science at Clarion University of Pennsylvania. His research interests include international trade, micro credit, group dynamics, economic growth and cultural dimensions, and teaching and pedagogical topics in business. He holds a Ph. D. in Agricultural Economics from Oklahoma State University.

Sandra $\mathbf{R}$ Trejos is a Professor of Economics at Clarion University of Pennsylvania. Her research interests include economic education, economic development, public sector, and international economics. She earned her Ph. D. in Economics from Oklahoma State University. 